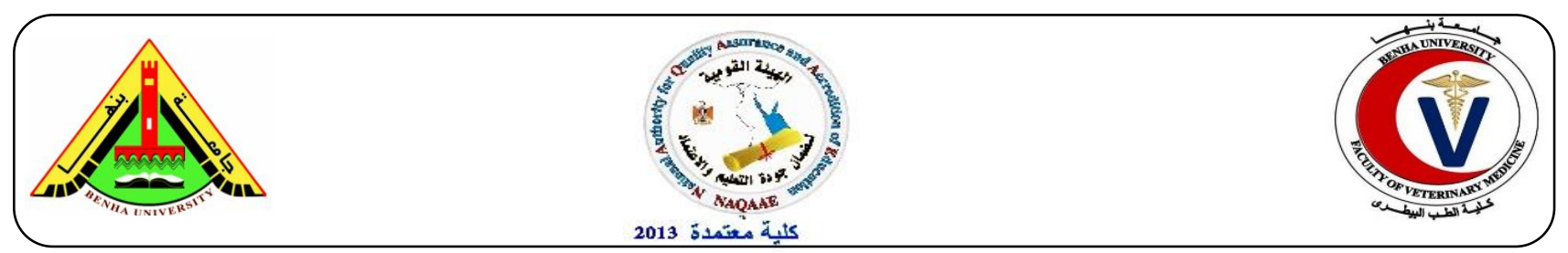

\title{
Serological and PCR-sequencing assays for diagnosis of Toxoplasma gondii and Neospora caninum infecting camels in Egypt
}

\author{
Nagwa Eid Ahmed ${ }^{1}$, Lubna Mohamed Al-Akabway ${ }^{1}$, Mohamed Yousef Ramadan ${ }^{1}$, Samah Mohamed \\ Abd El-Gawad ${ }^{1}$ and Mahmoud M. A.Moustafa ${ }^{2}$ \\ ${ }^{1}$ Parasitology Department, Fac. of Vet. Med., Benha University, Egypt \\ ${ }^{2}$ Genetics and Genetic Engineering Department, Fac. of Agriculture, Benha University
}

\section{ABSTRACT}

This study aimed to determine and evaluate the prevalence of the hidden coccidian tissue parasites (Toxoplasma gondii and Neospora caninum) in camels. For this purpose, 120 blood samples from two breed of camels (60Baldy and 60 Sudani) were collected through a period extend from September 2014 to August 2015. Samples were examined serologically for detection of anti-Toxoplasma gondii antibodies and by using PCR application for detection of Neospora caninum for the first time in Egypt. Results of indirect haemagglutination inhibition (IHAT) revealed that 6 out of $120(5 \%)$ serum samples were seropositive and the infection rate was the highest in both autumn and winter. No significance effect of age ( $>0.05)$ on the prevalence of infection among the examined camels, while the results of indirect Enzyme-Linked Immunosorbent assay (IELISA) showed that 63 out 120 serum sample examined by IHAT were positive (52.5\%). Using PCR application of 50 blood samples revealed that 12 (24\%) were positive for NC-5 region of Neospora caninum genome. Four positive purified PCR products were chosen randomly and for gene sequencing. The obtained sequences were registered in Gen Bank under accession numbers from MF980926.1 to MF980929.1. The analysis of DNA sequencing revealed that the obtained sequences were related to Neospora caninum with identity ranged from 98 and 99\%. we concluded that both ELISA and PCR-sequencing were sensitive methods in the diagnosis of the tissue parasites.

KeywordsToxoplasma gondii, Neospora caninum, IHAT, ELISA, PCR-sequencing

(http://www.bvmj.bu.edu.eg)

(BVMJ-33(2): 200-210, 2017)

\section{INTRODUCTION}

Toxoplasmosis is a disease produced by a coccidian parasite, Toxoplasma gondii; it is one of the utmost significant zoonotic diseases, world widely distributed and affecting almost all mammals and birds (Tenter et al. 2000). The clinical signs are non specific for disease diagnosis, so other recourse must be made to demonstrate either the organism or its antibodies (Manal 2003). Dye test, indirect immunofluorescence antibody test, direct and indirect haemagglutination test are traditional diagnostic methods for $T$. gondiiand it cannot detect recent infection. IELISA test has been developed for detection of the recent infection through estimation of $\operatorname{IgM}$, as compared to 
IgG, antibody (Uroquhart et al. 1996).

Neospora caninum is a global parasite, and it is the main reason of reproductive failure associated with abortion among ruminants, embryonic damage and maternal infertility (Dubey 1999). Diagnosis of neosporosis is hard, because of non-specific clinical signs and there are no parasitological examinations which can help to recognize the parasite (Atkinson et al. 2000). PCR technique provides a more fast and sensitive identification of the parasites. (Yamage et al. 1996).

Few previous traditional studies were carried out for diagnosis of either T.gondii or N.caninum in camels, accordingly this study focused on detection of alternative methods to improve diagnosis of these parasites. These include immunoassay and molecular based approach for early detection of the parasites in their subclinical phase, also determining the parasites prevalence and consequently correct time of interference by drugs.

\section{Material and Methods}

\section{2-1.Blood samples}

One hundred and twenty blood samples were randomly collected from apparently healthy camels of different breeds and ages during slaughtering in Toukh slaughterhouse, Qalyubia Governorate, Egypt. The blood samples were collected on non-heparinized tubes for serum separation. Each tube was labeled with (breed, season and age of the camel) and transferred in the ice box to Parasitology Lab, Parasitology Department, Fac. of Vet. Med. Benha University, Egypt.

For serological tests serum separation was carried out, samples were centrifuged at $3000 \mathrm{rpm}$ for 10 minutes. Sera were aspirated by Pasteur pipettes in clean and dry
Eppendorf tubes, labeled with the serial number and stored at $-20{ }^{\circ} \mathrm{C}$ until use.

Another 50 blood samples were collected on sterilized EDTA tubes and labeled with the serial number for the total genomic DNA extraction method.

\section{2-2.Detection of Toxoplasma antibodies}

\section{2-2.1.Indirecthaemagglutinationtest (IHAT)}

IHAT was carried out for detection of Toxoplasma antibodies in sera of tested camels using Toxo- IHA-Fast kits( ABC Diagnostic) according to manufacturer's instructions (El-Metenawy 2000).

\section{2-2.2. Indirect Enzyme-Linked immunosorbent assay (IELISA)}

IELISA was used for detection and quantification of Toxoplasma antibody (IgG)using commercial Toxoplasma IgG enzyme immunoassay test kits (BioCheck,Inc.)(Al-Khatib 2011).

\section{3-PCR assay for detection of Neospora caninum}

\subsection{DNA extraction}

Extraction of total genomic DNA was carried out according to manufacturer instructions of Wizard Genomic DNA purification Kit (Promega) Cat\# no. A2360, according to Müller et al., 1996. Also, the obtained DNA samples were measured by Spectrophotometer at $260 \mathrm{~nm} / 280 \mathrm{~nm}$ to detect the concentration.

\subsection{PCR Assay}

$1 \mu \mathrm{g}$ of each DNA sample was screened by PCR to detect the NC-5 region of Neospora caninum genome using specific primers. The used specific primers were Forward-Np21.5'-

CCCAGTGCGTCCAATCCTGTAAC- ${ }^{\prime}$ ' and ReverseNp6.5'CTCGCCAGTCAACCTACGTCTTCT-3' 
according to Yamage et al. 1996. While the PCR reaction was selectively amplified in 25 $\mu 1$ reaction mixtures composed of $0.4 \mu \mathrm{M}$ of each primer, $400 \mu \mathrm{M}$ of dNTP mix, $2.5 \mu \mathrm{l}$ of 10x PCR reaction buffer, $2 \mathrm{mM} \mathrm{MgCl} 2,1.5$ units from GoTaq ${ }^{\circledR}$ Flexi DNA Polymerase (Cat. \#:M3008) and $0.5 \mu \mathrm{g}$ DNA as a template. The PCR program was done as follows: an initial step at $95^{\circ} \mathrm{C} / 3 \mathrm{~min}$, 35 cycles of $95^{\circ} \mathrm{C} / 1 \mathrm{~min}, 64.9{ }^{\circ} \mathrm{C} / 1 \mathrm{~min}$, $72^{\circ} \mathrm{C} / 1 \mathrm{~min}$, followed by a final extension at $72^{\circ} \mathrm{C}$ for 5 minutes and storing step forever at $4^{\circ} \mathrm{C}$. The amplified PCR products were visualized on $1.8 \%$ agarose gel stained with ethidium bromide and photographed under UV transilluminator.

\section{3.sequencing}

The PCR product bands (337bp) were excised from gels and placed in a $1.5 \mathrm{ml}$ clean microcentrifuge tube. PCR products were purified using the Qiaquick Gel Extraction Kit (Cat. \#: 28704) following the manufacturer instructions. DNA was eluted in $50 \mu 1$ of nuclease-free water. Sequencing was performed on the purified PCR products by a commercial provider (Analysis, company, Egypt).

The obtained sequence for NC-5 region of Neospora caninum genome was analyzed with different bioinformatics tools. NEB cutter V2.0 software was used to create restriction map and to identify GC and AT ratios of the obtained sequence (Vincze et al. 2003, http://nc2.neb.com/NEBcutter2/). While Jalview software was used to show SNPs, GAPs and consensus regions resulted from the alignment of the obtained sequences and the nearest sequences in NCBI database (http://www.jalview.org/). The obtained sequences were submitted in the Gen Bank under accession numbers MF980926.1, MF980927.1, MF980928.1,and MF980929.1 of Neospora caninum (http://www.ncbi.nlm.nih.gov). Construction of the phylogenetic trees was done using Clustal Omega and MEGA7 software.

\section{4-Statistical analysis}

The Statistical analysis was carried out using ANOVA with five factors under significance level of 0.05 for the whole results using SPSS (ver. 22).Data were treated as complete randomization design according to Steel et al. (1997). Multiple comparisons were carried out applying LSD.

\section{Results}

3-1.infection rate of Toxoplasma gondii by IHAT test

The obtained results revealed that antibodies of $T$. gondii (IgG/ IgM) were detected in 6 out of 120 tested serum samples $(5 \%)$. The infection rate was the highest in both autumn and winter $(6.7 \%)$. On the other hand, the infection rate $(3.3 \%)$ was recorded in both summer and spring season (Table 1).The infection rate was higher among Baldy than Sudani breed (6.67 and $3.33 \%$ respectively).No significance effect of age ( $p>0.05$ )on the prevalence of infection among the examined camels (Table 2).

\section{3-2.Indirect Enzyme-linked immunosorbent assay (IELISA)}

The results of IELISA showed that out of 120 tested serum samples $63(52.5 \%)$ were sero-reactive. The infection rate was higher in the winter $(76.7 \%)$, followed by summer $(53.3 \%)$, while the infection was similar in both spring and autumn (40\%) (Table3). The infection rate was higher in Baldy than Sudani breed (55\% and 50\%, respectively).The Baldy and Sudani camels aged from 1-5 years had lower infection rate than those aged from 6-10 years $(47.5 \%$ and $55 \%$ respectively). (Table 4). 
Upon comparing the results of IHAT and ELISA test, it was cleared that IELISA test was significantly $(p>0.05)$ more sensitive than IHAT for detection of $T$. gondii in camels in different season of the year (Table $5)$.

\section{3-3.Neospora caninum}

PCR analysis of 50 blood samples could amplify $337 \mathrm{bp}$ of NC-5 gene of $N$. caninum in 12 samples (24\%) (Table 6, Fig 1). The peak of infection was recorded in summer $(57.1 \%)$ and lowest infection rate was in spring $(8.3 \%)$ and no infection was recorded in winter (Table 6). The infection was nearly similar in both Baldy and Sudani breed (24.2 and $23.5 \%$, respectively). The infection rate was higher in Baldy and Sudani camels aged from 6-10 years (27.27\% and $28.57 \%$, respectively) than those aged from $1-5$ years $(18.18 \%$ and $0.0 \%$, respectively) (Table 7 ).

\section{Gene sequencing of $N$. caninum isolates}

PCR- sequencing of the amplified product of NC-5 region of $N$. caninum revealed that the obtained sequences of the isolates have belonged to $N$. caninum. The isolates were related to the order Eucoccidiorida and Sarcocystidae family. The obtained DNA sequences were aligned and compared with sequence data for other $N$. caninum isolates available in the NCBI database using the BLAST alignment algorithm. The assembled sequences were submitted to NCBI Database under accession numbers MF980926.1, MF980927.1, MF980928.1, and MF980929.1 of $N$. caninum. The BLAST alignment showed that the nearest deposited sequences in database to the obtained sequences were (GU300774.1), (KX683873.1), (EF202080.1) and (JF937547.1) of $N$. caninum with identity ratio $99 \%, 98 \%, 98 \%$ and $99 \%$ respectively. The phylogenetic trees analysis confirmed the same identity ratios on the roots of clades
(Fig.2) Moreover, the single nucleotide polymorphism (SNP) results revealed that there were few SNPs and GAPs between the obtained sequence and the nearest ones registered in NCBI Database (Fig. 3) . Additionally, the expected restriction maps of the obtained sequences MF980926.1, MF980927.1, MF980928.1, and MF980929.1 displayed different endonucleases sites, hence these maps offer preliminary step with great importance in determining the recognition sites for different endonucleases in molecular marker studies like RFLP-PCR. Also, the maps illustrated that the GC and AT contents were different for each obtained sequence as shown in Fig. 4 (A, B, C, and D). 
Table 1. Seasonal prevalence of toxoplasmosis in camels by using IHAT.

\begin{tabular}{llllll}
\hline \multirow{2}{*}{ Items } & \multicolumn{2}{l}{ Season } & & & \\
\cline { 2 - 6 } & Autumn & Winter & Spring & Summer & Total \\
\hline Examined samples & 30 & 30 & 30 & 30 & 120 \\
Infected samples & 2 & 2 & 1 & 1 & 6 \\
$\%$ & 6.67 & 6.67 & 3.33 & 3.33 & 5 \\
\hline
\end{tabular}

Table 2.Prevalence of toxoplasmosis using IHAT among different ages and breeds of camels

\begin{tabular}{|c|c|c|c|c|c|c|c|}
\hline \multirow[t]{2}{*}{ Age } & \multicolumn{2}{|c|}{$\leq 5$ years } & \multicolumn{2}{|c|}{$\geq 5$ years } & \multicolumn{2}{|l|}{ Total } & \multirow[t]{2}{*}{$\%$} \\
\hline & Exam & infected & exam & Infected & Exam & infected & \\
\hline Baldy & 29 & 2 & 31 & 2 & 60 & 4 & 6.7 \\
\hline Sudani & 11 & - & 49 & 2 & 60 & 2 & 3.3 \\
\hline Total & 40 & 2 & 80 & 4 & 120 & 6 & 5 \\
\hline$\%$ & 5 & & 5 & & & & \\
\hline
\end{tabular}

Table 3. Sero-prevalence of Toxoplasma IgG by using IELISA.

\begin{tabular}{lccc}
\hline Season & Examined & \multicolumn{2}{c}{ Infected } \\
\cline { 4 - 4 } & & No. & $\%$ \\
\cline { 4 - 4 } Autumn & 30 & 12 & 40 \\
Winter & 30 & 23 & 76.7 \\
Spring & 30 & 12 & 40 \\
Summer & 30 & 16 & 53.3 \\
Total & 120 & 63 & 52.5 \\
\hline
\end{tabular}

Table 4. Prevalence of toxoplasmosis among different ages and breeds of camels by using IELISA

\begin{tabular}{|c|cc|c|c|c|c|c|}
\hline \multirow{2}{*}{ Age } & \multicolumn{2}{|c|}{ 1-5 years } & \multicolumn{2}{c|}{ 6-10 years } & \multicolumn{2}{|c|}{ Total } & \multirow{2}{*}{$\%$} \\
\cline { 2 - 7 } Breed & Exam & infected & exam & Infected & exam & infected & \\
\hline Baldy & 29 & 14 & 31 & 19 & 60 & 33 & 55 \\
Sudani & 11 & 5 & 49 & 25 & 60 & 30 & 50 \\
Total & 40 & 19 & 80 & 44 & 120 & 63 & 52.5 \\
$\%$ & \multicolumn{2}{c}{47.5} & 55 & & & \\
\hline
\end{tabular}

Table 5. Comparison between IHAT and IELISA results in different seasons

\begin{tabular}{ccc}
\hline & \multicolumn{2}{c}{ Serological tests } \\
\cline { 2 - 3 } Season & IHAT & IELISA \\
\hline Autumn & $6.67 \pm 0.21^{\mathrm{b}}$ & $40.00 \pm 0.21^{\mathrm{a}}$ \\
Winter & $6.67 \pm 0.32^{\mathrm{b}}$ & $76.67 \pm 0.12^{\mathrm{a}}$ \\
Spring & $3.33 \pm 0.33^{\mathrm{b}}$ & $40.00 \pm 0.53^{\mathrm{a}}$ \\
Summer & $3.33 \pm 0.23^{\mathrm{b}}$ & $53.30 \pm 0.12^{\mathrm{a}}$ \\
\hline
\end{tabular}

- $\quad$ Data are expressed as Mean \pm S.E. for each group 
Ahmed et al. (2017) (BVMJ-33(2): 200-210

- $\quad$ a significant from season at the same row with one way ANOVA at $\mathrm{P}<0.05$.

- ${ }^{\mathrm{b}}$ significant from season at the same row with one way ANOVA at $\mathrm{P}<0.05$.

Table 6. Seasonal prevalence of $N$. caninum among the examined camels using PCR assay.

\begin{tabular}{lccccc}
\hline \multirow{2}{*}{ Items } & \multicolumn{5}{c}{ Season } \\
\cline { 2 - 6 } & Autumn & Winter & Spring & Summer & Total \\
\hline Examined & 12 & 12 & 12 & 14 & 50 \\
Infected & 4 & 2 & 1 & 5 & 12 \\
$(\%)$ & 33.3 & 16.7 & 8.3 & 35.7 & 24 \\
\hline
\end{tabular}

Table 7. Prevalence of N. caninum detected by PCR method in different breeds and age of camels

\begin{tabular}{|c|c|c|c|c|c|c|c|c|}
\hline \multirow{2}{*}{ Breed Age } & \multicolumn{3}{|c|}{$\leq 5$} & \multicolumn{3}{c|}{ Total } \\
\cline { 2 - 9 } & Exam & Infected & $\%$ & Exam & Infected & $\%$ & Infected & $\%$ \\
\hline Baldy (33) & 11 & 2 & $18.18^{\mathrm{aA}}$ & 22 & 6 & $27.27^{\mathrm{aA}}$ & 8 & 24.2 \\
Sudani (17) & 3 & 0 & $0^{\mathrm{aA}}$ & 14 & 4 & $28.57^{\mathrm{aA}}$ & 4 & 23.5 \\
Total (50) & 14 & 2 & 14.3 & 36 & 10 & 27.8 & 12 & 24 \\
\hline
\end{tabular}

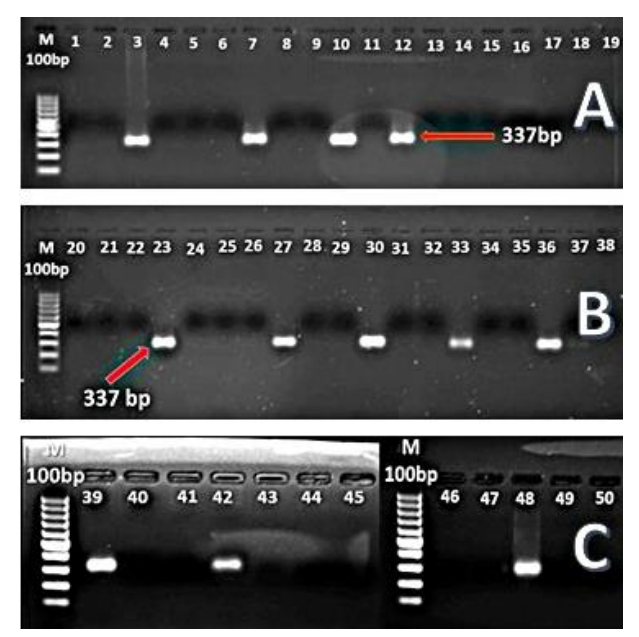

Fig.1, (A,B,C).PCR amplification of $337 \mathrm{bp}$ of $N$. caninumin $1.8 \%$ agarose gelthe positive samples were

Lane $3,7,10,12,23,27,30,33,36,39,42$, and 48 were positive .

Lane M: DNA ladder of $100 \mathrm{bp}$ 


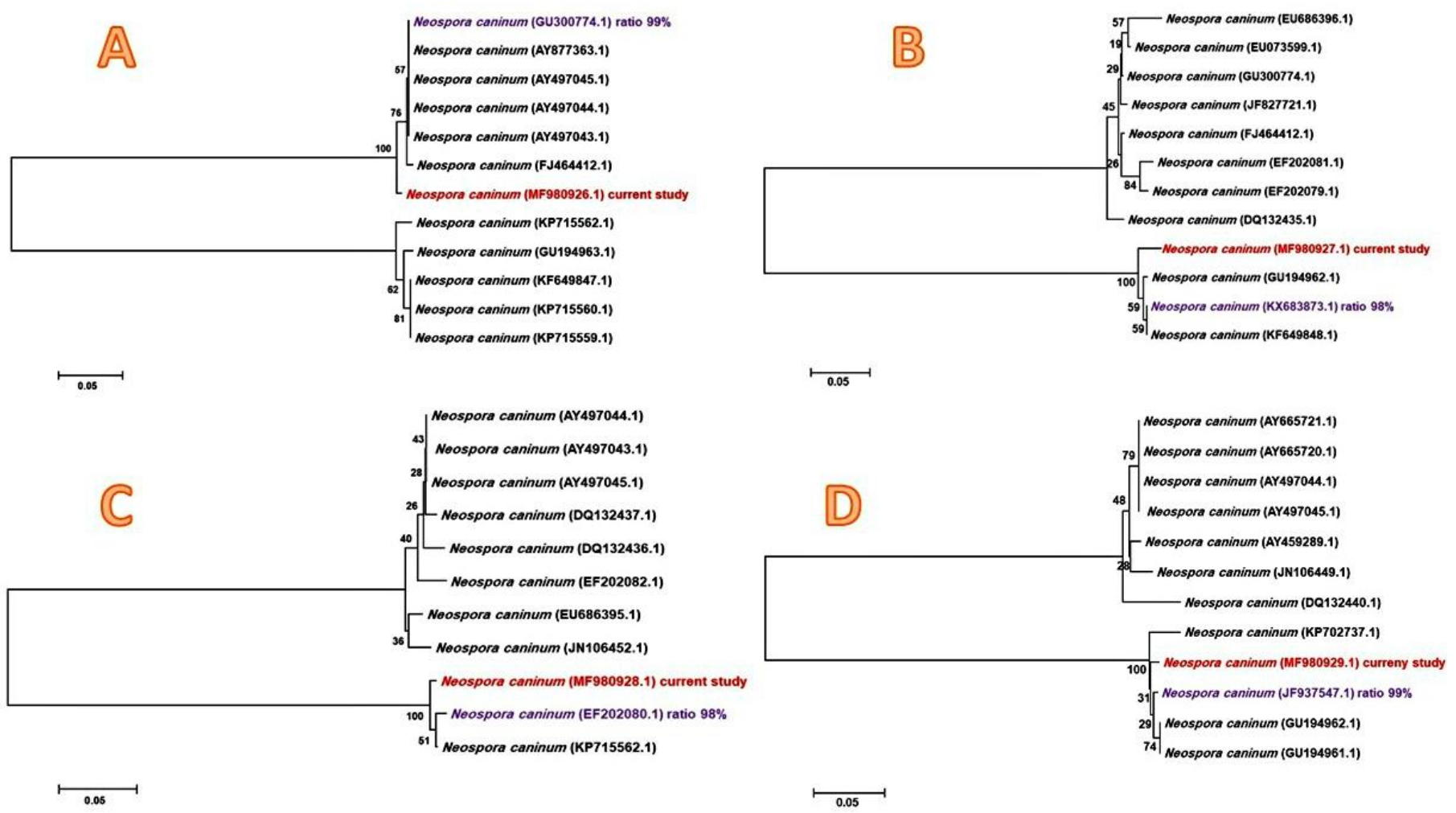

Fig.2. Phylogeny trees analysis produced by the Neighbor-Joining method among N. caninum isolated in the present study (A,B,C,D) and the isolate obtained from the gene bank using Clustal Omega tool and MEGA 7.0.21 software.
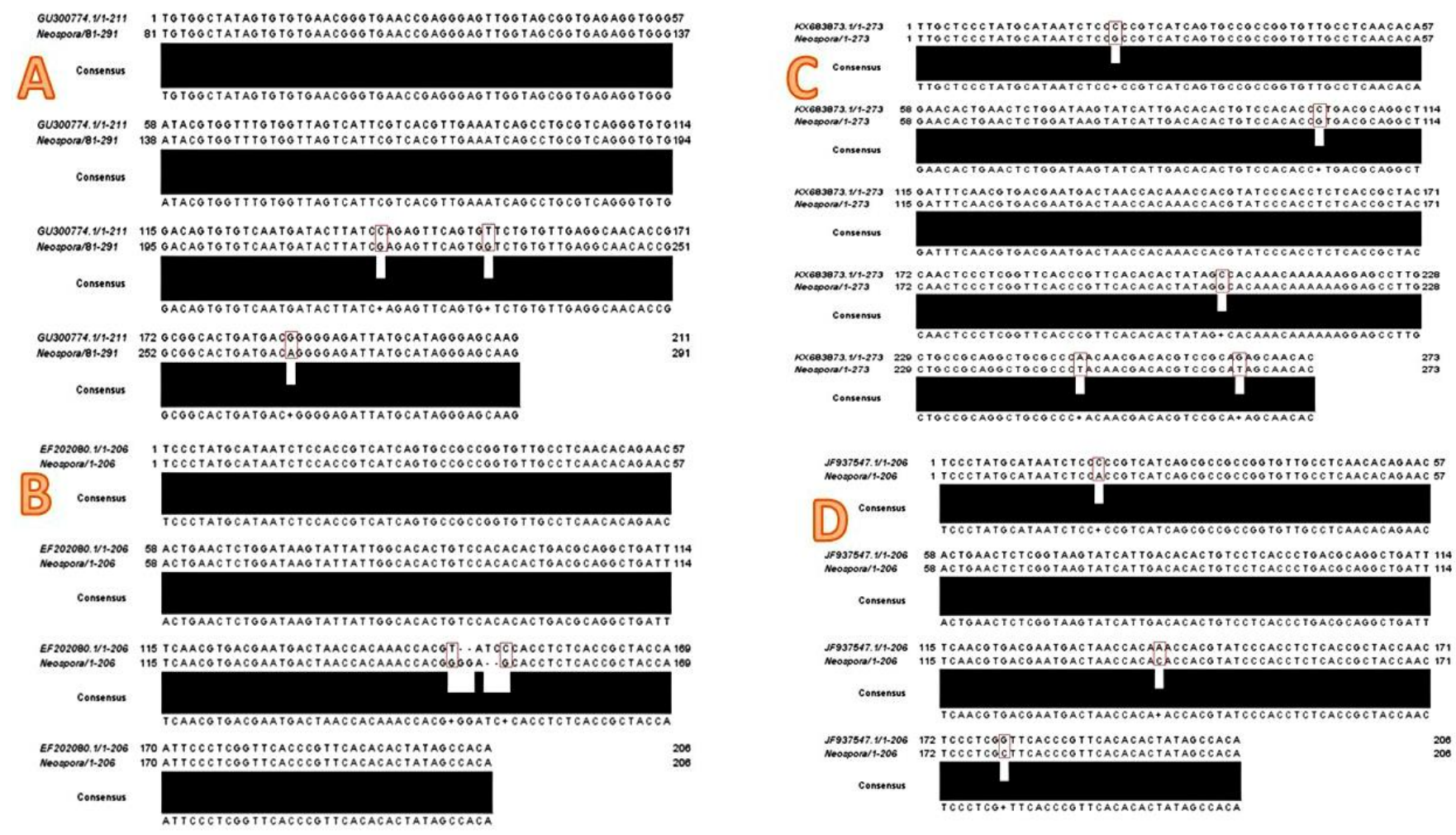

Fig.3. Single nucleotide polymorphism (SNP) images of the obtained sequences MF980926.1, MF980927.1, MF980928.1, and MF980929.1 for $N$. caninum with the nearest ones GU300774.1,KX683873.1, EF202080.1 and JF937547.1 deposited in Gen Bank respectively 

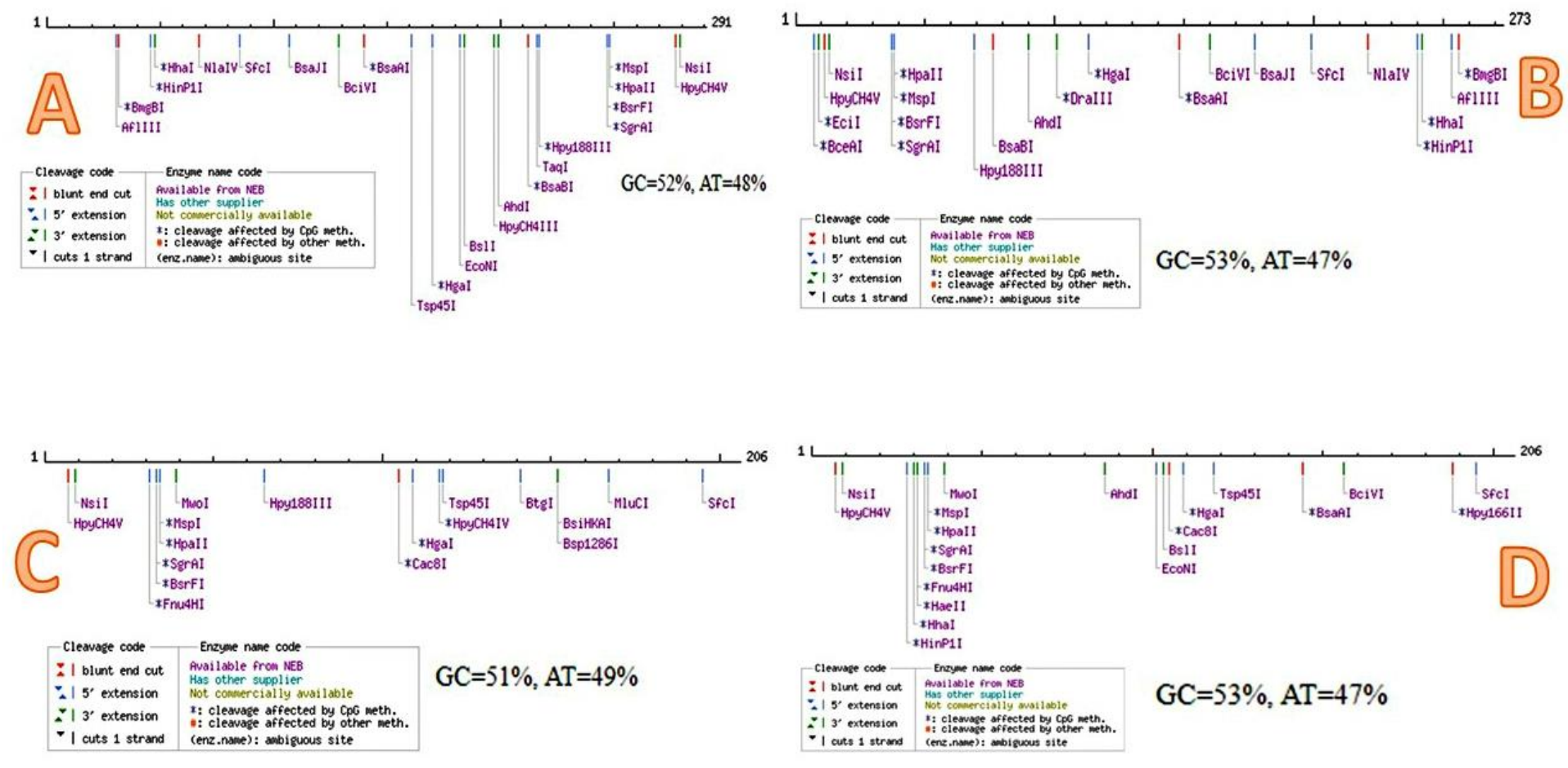

Fig.4. Restriction maps of the obtained sequences MF980926.1, MF980927.1, MF980928.1, and MF980929.1 for $N$. caninum produced by online software NEB cutter, version 2 http://nc2.neb.com/NEBcutter2/. Also, the Maps (A, B, C, and D) showed the ratios of GC an AT contents for the obtained sequences.

\section{Discussion}

Upon using IHAT for diagnosis of T. gondii, IgG and $\operatorname{IgM}$ were detected in 6 out of 120 serum samples $(5 \%)$ and the rate of infection was not affected by the age of the examined camels. This result agreed with the results previously recorded by Sadrebazzaz et al. (2006) in Iran (4.2\%), Doosti et al. (2014) in Iran (6.60\%) and Kadle (2014) in Somalia $(6.3 \%)$. Higher infection rates were obtained in Egypt by El-Ridi et al. (1990), in Sudan by Elamin et al. (1992), Khalil et al. (2007) and Khalil and Elrayah (2011) which were (25\%, 67\%, 22.2\% and $22.9 \%$ respectively). A lower results was recorded by Wang et al. (2013) in China (3\%).On the contrary ElMetenawy (2000) found that all the examined camels in Egypt were sero-negative for $T$. gondii.

With respect to the seroprevalence of $T$. gondii using IELISA test, the present study found that the $\operatorname{IgG}$ of toxoplasmosis was detected in $52.5 \%$ of the examined camels. Nearly similar results were recorded by AlKhatib (2011) in Saudi Arabia (45.44\%) and Gebremedhin et al. (2014) in Ethiopia (40.49\%), while this finding was higher than that obtained by Omar (2005) in Egypt, AlMohammed (2011) and Marai et al. (2014) in Iraq $(10 \%, 8 \%$ and $16.4 \%$, respectively). The obtained result disagreed with the result of Ibrahim et al. (2015) who found a higher infection rate $(96.9 \%)$ in Sudan .The highly obtained prevalence of $\mathrm{T}$. gondii in this study 
may be attributed to that the stray cats were widely spread in camels farms leading to contamination of the environment with the oocysts that were shed in their feces. The difference of Toxoplasma seroprevalence in our study and previous studies was ascribed to the difference of employed serological tests used in the diagnosis of the parasite, the initial serum dilution, climatic variation from region to another, age of the examined camels and frequency of felines on the farms. Concerning to the relationship between age of the examined camels and the infection rate, the current study showed that there was a difference in the prevalence of infection among the different age groups. IELISA test showed that the camels of ages ranged from 6-10 years had higher infection rates than the camels of ages ranged from 1-5 years. These results were similar to that observed by Elamin et al. (1992) in Sudan, Al-Mudhfer and Kshash (2012) in Iraq, Hamidinejat et al. (2013) in Iran, Gebremedhin et al. (2014) in Ethiopia and Marai et al. (2014) in Iraq. Moreover, the prevalence rate of seroreactivity increased by increasing age of the camels. The obtained results disagreed with the results of Khalil et al. (2007) in Sudan, Manal and Maijd (2008) in Sudan and Wang et al. (2013) in China who noted that there was no significant difference in the prevalence among camels of different age group.

The obtained results cleared that IELISA was more sensitive than IHAT for detection of $\mathrm{T}$. gondii in camels, as the infection rate was $52.5 \%$ and $5 \%$ by IELISA and IHAT respectively. It's cleared that using of ELISA test for diagnosis of toxoplasmosis in camels was more sensitive than IHAT test as it gave more than ten times infected camels by IHAT, also it could be applied in largescale of epidemiological studies.
According to the available works of literatures, it was the first time to carry out PCR and sequencing methods for detection of $N$. caninum infecting camels in Egypt. The current results showed that 12 samples out of 50 camels $(24 \%)$ were $N$. caninum positive, the peak of infection was recorded in the summer season and the infection was higher in Baldy than Sudani breed. The infection was higher in camels aged from (6-10 years) than those aged from (1-5 years) with prevalence 27.8 and $14.3 \%$ respectively. Lower results were obtained by Hilali et al. (1998) and Omar (2005) in Egypt (3.7\%, 8\%, respectively), Sadrebazzaz et al. (2006) in Iran, (5.8\%), Al-Anazi (2011) Saudi Arabia (5.6\%) and Hamidinejat et al., (2013) Iran (3.9\%). On the other hand, the higher results were obtained by Mentaberre et al. (2013) in Spain, (86\%)and Ibrahim et al. (2015) in Sudan, (38.5\%). Such difference may be attributed to changes in the methodology of diagnosis of Neosporosis.

\section{Conclusion}

1- Both IELISA and PCR-sequencing could detect the infection of $52 \%$ and $24 \%$ of camels with $T$. gondii and $N$. caninum respectively proving that they are highly sensitive techniques for detection of the tissue parasites which are difficult to be diagnosed using traditional methods.

2-It was the first time to apply PCR application and sequencing assay for diagnosis of $N$. caninum in Egypt.

\section{References}

Al-Anazi AD 2011.Prevalence of Neospora caninum and Toxoplasma gondii antibodies in Sera from camels in Riyadh province, Saudi Arabia. J of Egyptian Society of Parasitol 41(2): 245-250. 
Al-Khatib RM 2011 .Serological studies of Toxoplasma gondii infection in camels. Assuit Vet Med J 57(130): 223-232.

Al-Mohammed HI 2011.Seroprevalence of Toxoplasma gondii infection in cats, dogs and ruminant animals in Al-Ahsa area in Saudi Arabia. Research J of Med Sci 5(4): 190-192.

\section{Al-Mudhfer SM,Kshash QH 2012.} Serological study about Toxoplasmosis in camels. Al-Qadisiya $\mathrm{J}$ for Agriculture Sciences 2(1): 102-107.

Atkinson R, Harper PA, Reichel MP, Ellis JT 2000. Progress in the serodiagnosis of Neospora caninum infections of cattle.Parasitol Today16:110-114.

Dubey JP 1999.Neosporosis in cattle: biology and economic impact.J of American Vet Med Asso 214:1160-1163.

Elamin EA, Elias S,Daugschies A, Rommel M1992. Prevalence of Toxoplasma gondii antibodies in pastoral camels (Camelus dromedarius) in the Butana plains, mid-Eastern Sudan.VetParasitol 43(3/4):171-175.

El-Metenawy TM 2000.Seroprevalence of Toxoplasma gondii antibodies among domesticated ruminants at Al-Qassim region, Saudi Arabia. Deutsche TierarztlicheWochenschrift107(1):3233.

El-Ridi AMS, Nada SMM, Aly AS, Habeeb SM, Abdul-Fattah MM 1990. Serological studies on Toxoplasmosis in Zagazig slaughterhouse. J. of the Egyptian Society of Parasitol 20(2):677681.

Gebremedhin EZ, Yunus HA, Tesfamaryam G,Tessema TS, Dawo F, Terefe G,Di Marco V, Vitale M2014. First report of
Toxoplasma gondii in camels (Camelusdromedarius) in Ethiopia: bioassay and seroepidemiological investigation. BMC Vet Res 10:222,

Hamidinejat $\mathrm{H}$, Ghorbanpour M, Rassli A,Nouri M, Hekmatimoghaddam S, Namavari M, Pourmehdi-Borojeni M, Sazmand A 2013.Occurance of antiToxoplasma gondii and Neospora caninum antibodies in camels in the center of Iran. Turkish $\mathrm{J}$ of Vet and Animal Sci 37(3): 277-281.

Hilali M, Romand S, ThulIIez P, Dubey JP 1998. Prevalence of Neospora caninum and Toxoplasma gondii in sera from camels from Egypt. Vet Parasitol 75: 269-271.

Ibrahim AM, Ismail AA, Angara TamadorElkhansa E, Osman OM2015.Detection of Antibodies against Toxoplasma gondii and Neospora caninum in Dairy Camels from the Khartoum State, Sudan.The Regional Conf. of Camel Management and Prod, under Open range System (RCCMPR), KhartoumSudan, 2nd -4th March,Sudan Journal of Science and Technology, 16:60-68.

Kadle AAH 2014. Seroprevalence of Toxoplasmosis in domestic animals in Benadir region, Somalia. Open $\mathrm{J}$ of Vet Med 4(8):170-174.

Khalil KM, Elrayah IE 2011. Seroprevalence of Toxoplasma gondii antibodies in farm animals in Sudan. J.of Vet Med and animal Health, 3(3):36-39.

Khalil KM, Rahman AEA, Yassir MMA, Ahmed OM, Elrayah AA 2007. Prevalence of Toxoplasma gondii antibodies in camels and their herders in three ecologically different areas in 
Sudan. J. of camel practice and Res 14(1):11-13.

Khamesipou F, Doosti A, Mobarakeh HI, Komba EVG 2014.Toxoplasma gondii in cattle, camel and sheep in Isfahan and chaharmahalva Bakhtiary provinces Iran. Jundishapur $\mathrm{J}$ of Microbiol 7(6).e17460.

Mahmoud MHS, Al-RubaieASM, Al-Jeburii KOS, Taha AA 2014.Serosurvillance on Toxoplasmosis in Camels (Camelus dromedarius) at Al-Najaf Province.J VetMedSci 5 (2): 204-210.

Manal YL 2003.Studies on Toxoplasma and Sarcocystis from camels (Camelus dromedarius) in the Sudan.PhD.Thesis, University of Khartoum, Sudan.Pp1 08.

Manal YI, Maijd AM 2008. Association of diarrhea with congenital toxoplasmosis in calf camels. Int $\mathbf{J}$ of Trop Med 3(1): 10-11.

Mentaberre G, Gutierrez C, Rodriguez NF, Joseph S, Gonzalez-Barrio D,CabezonO,de la Fuente J, Gortazar C, Boadella M 2013. A transversal study on antibodies against selected pathogen in dromedary camels in the Canary Island, Spain. Vet Microbiol 167(3/4): 468-473.

Müller N, Zimmermann V, Hentrich B, Gottstein B 1996. Diagnosis of Neospora caninum and Toxoplasma gondii Infection by PCR and DNA Hybridization Immunoassay. J Clinc Microbiol 2850-2852.

Omar SFA2005.Serological diagnosis of Toxoplasma gondii and Neospora caninum in cows, ewes, she-camels and dogs by Competitive ELISA and
Capture ELISA. Vet Med J 53(2):625634.

Sadrebazzaz A, Haddadzadeh H,Shayan P 2006. Seroprevalence of Neospora caninum and Toxoplasma gondii in camels in Mashad, Iran. Vet ClincPathol 35(4):484.

Steel R,Torrie J, Dickey D 1997. Principles and procedures of Statistics: A Biometrical Approach, 3rd ed., McGraw-Hill, New York, NY.

Tenter AM, Heckeroth AR, Weiss LM 2000. Toxoplasma gondii: from animals to humans. Int J Parasitol 30: 1217-1258.

Uroquhart GM, Armour J, Duncan JL, Jennings FW 1996. Toxoplasma. 2nd Vet Parasitol Edition, Blackwell Science Ltd. London 234- 238.

Wang YH, Meng QZ 2013.Toxoplasma gondii infection in Bactrian camel in China. Vet Parasitol 192(1/3): 288-289.

Yamage M, Flechner OM, Gottstein B 1996.Neosporacaninum:specific oligonucleotide primers for the detection of brain "cyst" DNA of experi- mentally-infected nude mice by the polymerase chain reaction (PCR). $\mathrm{J}$ Parasitol 82: 272-279 